\section{CITRININ-AN INDUCER OF PERMEABILITY CHANGES IN EREMOTHECIUM ASHBYI}

\author{
Vladimír Betina \\ and Helena Baráthová
}

Department of Microbiology and Biochemistry, Slovak Polytechnical University, Bratislava, Slovakia, ČSSR

(Received for publication September 10, 1968)

Narrowing effects of citrinin on representatives of major groups of the fungi were reported recently ${ }^{1)}$. Besides the narrowing of growing hyphae, growth of short side branches in almost at right angles to the hyphal tips of Botrytis cinerea and also yeast-like growth of the the dimorphic fungus Paecilomyces viridis, can be induced by citrinin ${ }^{2}$. The present report is concerned with the effects of the antibiotic on permeability of Eremothecium ashbyi which is known to produce riboflavin.

\section{Materials and Methods}

A low producing strain of Eremothecium ashbyi was grown in Petri dishes on malt agar which contained a range of concentrations of citrinin. During incubation at $28^{\circ} \mathrm{C}$ for 7 days diameters of the growing colonies were measured.

Effects of citrinin on riboflavin synthesis

Fig. 1. Growth of Eremothecium ashbyi on malt agar containing citrinin. Temperature $28^{\circ} \mathrm{C}$.

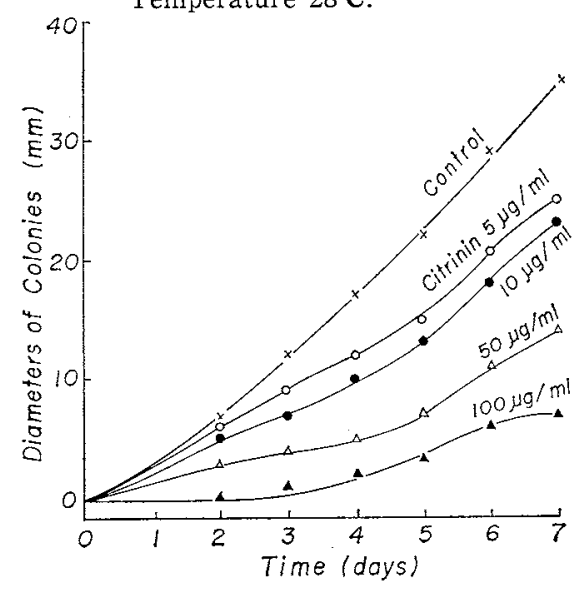

Fig. 2. Riboflavin production by Eremothecium ashbyi and its distribution in presence of antibiotics. Top: riboflavin in filtrates; bottom: riboflavin in mycelia.

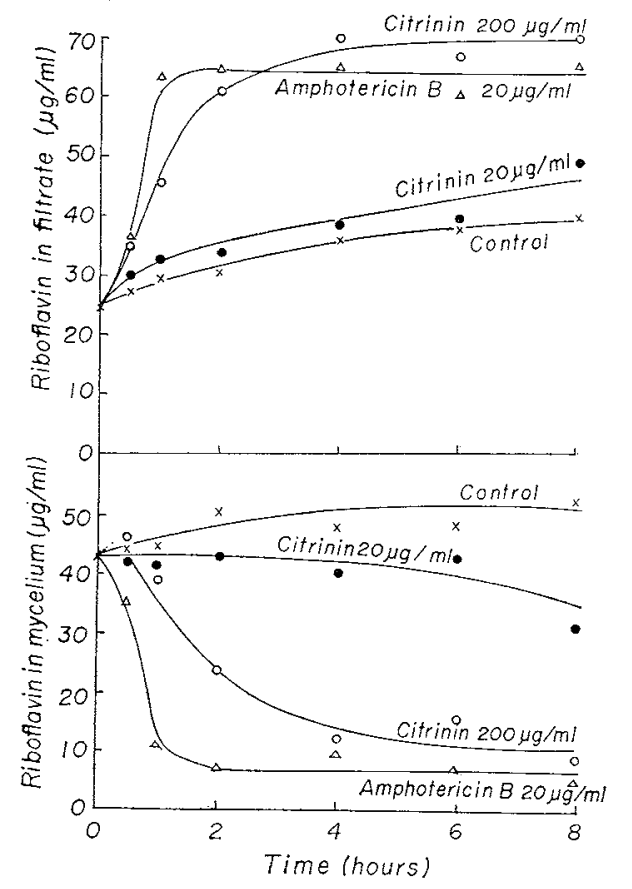

and distribution were compared with those of amphotericin B which inhibits riboflavin production and causes its rapid leakage from mycelium of this fungus ${ }^{3)}$.

Volumes $80 \mathrm{ml}$ of a 40 hours old submerged culture of $E$. ashbyi, obtained as described $^{37}$, were transferred into duplicate sets of $500 \mathrm{ml}$ flasks. Solution of citrinin or amphotericin $\mathrm{B}$ in dimethyl sulphoxide were added to the cultures to the desired concentrations. The final concentration of dimethyl sulphoxide in all flasks including the controls was $1 \%$. The flasks were then incubated on a reciprocating shaker at $28^{\circ} \mathrm{C}$ and samples were removed at intervals. Riboflavin contents in media and in mycelia were estimated using techniques described ${ }^{3)}$.

\section{Results and Discussion}

When antifungal activity of citrinin against Eremothecium ashbyi was studied, an inhibition of growth was observed (Fig. 1) which was much higher than that reported for other fungi ${ }^{1}$. At the two highest 
concentrations used, 50 and $100 \mu \mathrm{g} / \mathrm{ml}$, diffusion of yellow pigments from the colonies of $E$. ashbyi occurred which could mean that citrinin damaged cell membranes. This was confirmed in the experiments in which riboflavin production in the presence of citrinin was examined.

The following results were obtained (Fig. 2). Citrinin at $200 \mu \mathrm{g} / \mathrm{ml}$ stopped the synthesis of ribollavin after about 2 hours, while amphotericin B at $20 \mu \mathrm{g} / \mathrm{ml}$ stopped it immediately. Like amphotericin B, citrinin greatly increased leakage of riboflavin from the mycelium of $E$. ashbyi. Citrinin was much less active at $20 \mu \mathrm{g} / \mathrm{ml}$, both antibiotics were inactive at $2 \mu \mathrm{g} / \mathrm{ml}$.

Our findings indicate that citrinin exhibits its antifungal activity by damaging cell membranes. Further investigations are necessary to conclude whether or not this is the primary effect of citrinin on fungal cells. Even if this should prove to be the case its mode of action at the molecular level remains unknown. It only can be stated that, besides other known inhibitors of functions of cell membranes, citrinin is an agent inducing changes of permeability in fungi.

In another paper from our laboratory ${ }^{2}$ it was reported that some other antibiotics including polyenes exhibit morphological changes in fungi similar to those induced by citrinin. Relationships between the mode of action of antifungal antibiotics and their effects on morphology of fungi are hitherto little known. Studies in this field could help to elucidate some aspects of morphogenesis in fungi.

\section{References}

1) Robinson, P. M. \& D. PARK: Citrinin, a fungistatic antibiotic and narrowing factor. Nature $211: 883 \sim 884,1966$.

2) Bardthoví, H.; V. Bertina \& P. Nemec: Morphological changes of fungi induced by antibiotics. (in press)

3) Betina, V.; H. Barathová, Z. Barath \& P. Nemec; Different sensitivities of plant, fungal and animal cell membranes to polyene antibiotics. (in press) 